\title{
THE LITURGICAL SONGS IN CREATIVE WORK OF BOHDAN-IGOR ANTONYCH
}

\section{Dmytriv I. I.}

\section{INTRODUCTION}

The creative work of Bohdan-Igor Antonych is one of the most significant pages of our literature, it has a genuine originality in the comprehension of artistic reality and exceptional depth in reproducing the specifics of the religious worldview, and yet it is distinguished by genre versatility, a wide palette of poetic means, high level of subjectivity in the poetic interpretation of traditional plots. Given this, the poetical heritage of B.-I. Antonych remains a fertile ground for literary studies. That's why, the "The Great Harmony" collection needs some rethinking, because it is a unique poetic attempt of dipping into the mystery of human existence, the desire to find answers to difficult life questions in the relationship with the Creator.

The use of symbols, especially religious ones is characterized for the creative work of B.-I. Antonych. Among Christian symbolism, liturgical symbolism plays an important role, however the Liturgy, the basis of the Christian life, is inalienably connected with the Scripture. According to Christian teaching, there are two ways to get acquainted with God: the first is in the Eucharist, which is performed at the Liturgy; the second is to receive the Word of God. There is a close connection between the Bible and the Service of God, since the Liturgy is largely constructed on the Scripture expressions.

The artistic reception of liturgical works is closely connected with the fact that music and singing are important means for achieving the mystical state of unity between a man and God in the works of B.-I. Antonych. In his poetry musical images are symbolized, are carriedan important semantic loading (for example, a harp, bell, violin). At the genre level, the author often uses psalms, hymns, songs; biblical stylization, allusions from the Scripture and famous liturgical works are typical for him. 
It is noticeable that some works of B.-I. Antonych are laid on music, including "Mater Dolorosa", "Christmas" ("God was born on a sleigh"), "Christmas carol" ("Carpenters hews sleighs from silver"). So, to express the ecstatic outliving of God, the poet sometimes not enough words, then music comes to the help, which is able to touch the subtlest strings of the soul and tunethe person for acceptance of mercy.

\section{Reception of Divine Liturgy in collection "The Great Harmony" by Bohdan-Igor Antonych}

Much of the works that have been included in collection "The Great Harmony" by Bohdan-Igor Antonych are poetic replaying of the Divine Liturgy. For example, works "Kyrie Eleison", "Gloria in Excelsis", "Credo", "Sanctus", "Agnus Dei" have identical names with parts of Liturgy of the Latin rite, and poems"Veni Sancte Spiritus", "Deus Magificus", "Te Deum Laudamus", "Veni Creator", "Confiteror", "Mater Dolorosa", "Mater Gloriosa" and "Salve Regina" are ideologically related to the hymnographic Christian tradition. It should be noted that the Divine Liturgy of both the Eastern and the Western Rites is deeply rooted in the Scripture, howeverthe psalms are actively used in it, the fragments from the Gospels and the Epistles of the Apostles are read, not to mention the spiritual connection between what is written in the Scripture and is performed at the Liturgy.

Alexander Schmemann points out that the concepts "symbols" and "symbolism"have become practically synonyms with the Byzantine Liturgy, because almost all liturgists understand the Divine Liturgy as a symbolic representation of the life of Jesus Christ, from birth in Bethlehem to the glorious ascension into Heaven ${ }^{1}$. The quintessence of the Christian Liturgy is the Eucharist, that is, Thanksgiving. Strictly speaking, the motive of thanksgiving, blessing, worship, the glorification of God is throughout in "The Great Harmony". Iryna Betko believes that in some metaphorical sense, "The Great Harmony" can be identified as a kind of open prayer².

1 Шмеман А. Символы и символизм византийской литургии: Литургические символы и их богословское истолкование. Синопсис. 2001. № 4/5. Ст. 74.

2 Бетко I. Осмислення нумінозного досвіду в поезії Богдана-Ігоря Антонича. Бетко I. Українська релігійно-філософська поезія. Етапи розвитку. Каtowice: Wydawnictwo Uniwersytetu Śląskiego, 2003. Ст. 200. 
Researcher V. Lepakhin, considering prayer as a verbal icon, gives it all the features of iconic image, namely: ontology, antinomy, canonicity, symbolism, synthetic and synergistic. The ontology is that the believer does not doubt about the presence of God, so prayer preserves the prototype of God. Antinomy: prayer preserves contradictions between two concepts, phenomena that mutually exclude one another. From the very beginning the sinful personappeals to the sinless Absolute, and by that appeal he brings himself nearer to God. Canonicity means that prayer is created according to a certain rule given to humanity by Jesus Christ in the doctrine of prayer in the Sermon on the Mount. The symbolism is realized in the fact that Christ, who created the doctrine that became the law of life for men, is the symbol of faith for Christians; prayer is also part of this symbol of faith. Synthetic - in prayer, the Earth is united with the Upper Powers, during prayer everything else becomes non-essential to the believer. Synergistic - the prayer word becomes an accumulator of energy state, a hidden factor of action, a symbol of synergy. Through prayer, the body's reaction andits energy increases so much that sometimes the believer feels exhausted after this action, as if purified from bad $^{3}$.

Theologians distinguish in the prayers the three stages of mastering the sacrum: the first is reading, worship, "cheerfulness"; the second is where the physical and spiritual appear as equivalent; the third is the action of prayer without words, without worship, even without thinking. Prayer is a true spiritual life in processual and action. Therefore, literary prayer must also accumulate spiritual effort. Prayer is a word of not indifferent person, a word that anyone can say, its emotional and spiritual accusation is also preserved in literary texts ${ }^{4}$.

In Christianity, the following basic types of prayers are distinguished: praise, request, gratitude, repentance prayer. In the New Testament, a similar division was mentioned: "[...] I exhort, that, first of all, supplications, prayers, intercessions, and giving of thanks, be made for all men" (1 Tim. 2, 1).

\footnotetext{
3 Лєпахін В. Ікона та іконічність. Львів: Свічадо, 2001. Ст. 145.

${ }^{4}$ Бовсунівська Т. Молитва як літературний жанр. Дивослово. 2003. № 7. Ст. 3.
} 
This thematic differentiation of prayers also concerns to the literary tradition where it is actually preserved. T. Bovsunivska adds "prayer to prayer" as a kind of literary formation, a modification of the liturgical nature of prayer ${ }^{5}$. In "The Great Harmony" there is a poem "Prayer" where the author praises the prayer as follows:

A mortal's prayer is like smoke,

it circles above a village like a white swan,

it blows along the crystal sky

like a curly-haired golden stem [...].

A mortal's prayer is like an eagle,

above the clouds it flies out from the earth's threshold,

and begins to quiver like a quail:

it catches sight of the fiery face of $\operatorname{God}^{6}$.

Prayers of praise of God and request aredominated in B.-I. Antonych. But the request is not for small earthly things, but for the gift of faith, for the gifts of the Holy Spirit, for the harmony of the soul. Such poems as "Deus Magnificus", "Magnificat", "Te Deum laudamus", "Te Deum laudamus, II" are an artistic illustration of the prayers-blessing. In these works, the author praises the Lord, praises His greatness, and admires His omnipotence and omnipresence. Each line of the poem testifies to the poet's faith in the only God the Father, the Almighty, the Creator of heaven and earth, of all things visible and invisible.

"A gratitude prayer, writes Fr. Alexander Men, is the most beautiful and purest among prayers. She seeks nothing, asks nothing, but only filled with joyful awareness of the mercy of God poured out on a person. For everything: for the eyes that see the sun and the beauty of the world; for ears that hear the harmony of sounds and the Word of God; for a mind that comprehends secrets; for a heart that is able to love - a person thanks for all of this ${ }^{7}$.

${ }^{5}$ Бовсунівська Т. Молитва як літературний жанр. Дивослово. 2003. № 7. Ст. 3.

6 Антонич Б. І. Повне зібрання творів / Передмова Миколи Ільницького; Упорядкування і коментарі Данила Ільницького. Львів: Літопис, 2009. Ст. 97-98.

7 Мень А. В. Таинство, Слово и Образ. Православное богослужение. Москва, 2001.Ст. 54. 
If we talk about the liturgical aspect of Antonych's poetry, it should be notedthat a noticeable feature of the poems mentioned above is their rooting in the psalms and other liturgical texts. The liturgical antiphons are the same "fragments of the psalms that have been preserved from the Jewish synagogue worship and contain, except the prayerfuland entreating, more praiseworthy and glorious element. The psalms are used not only in the Liturgy, but also as a part of all other worships"8. E. Ronkey thinks of the place of psalms in the prayer tradition: "Let's try to imagine the birth of the psalms. People prayed in a variety of situations, in joy and sorrow, after victory and on the brink of death, in the dark valleys and in the face of beauty, among the dust of the ways and incense of the temples: King (David) before the war and after sin, the shepherd, the poet, the sick, the Levite. And they all prayed so well, in such beautiful words, that God said, these words become mine, and I give them to people as my words, and they will give them to me as their words. Human words, becoming the words of God, become human words again. The Psalm is the word of man and the word of God, which are united once and for ever [...] Pray the psalms is more than religious thought"".

Iryna Betko notes that in the Ukrainian poetic tradition the Psalter's reception highlights a number of literary and artistic regularities. Thus, the correlation of proper imitative and specific author's factors in psalter's innovations determines the belonging of one or another of them to a certain receptive type. The researcher numbers five of these types: 1) the group of contexts of the first receptive type envisages the fullest possible reproduction of the features of the original by means of the recipient's language, except that super-task, the translator has no other purpose, as a rule; 2 ) the second receptive type is characterized by the preservation of all the compositional-content units of the original as the basis, which is updated by a fundamentally new artistic content, mainly through stylistic and versification decisions and implication; 3) in the third group, the interpreted original source,the reference to which is often contained in the

${ }^{8}$ Соловій М., о. Божественна Літургія: Історія - розвиток - пояснення. Львів: Свічадо, 1999. Ст. 221.

9 Ронкі Е. Закоханий і здивований Бог / Пер. з італ. К. Зінченко. Львів: Свічадо, 2015. Ст. 36-37. 
epigraph, is unmistakably read, but the new creation is completely independent of its prototype in all its formal and semantic features; 4) this group is a throughoutpsalter's stylizations that, at external similarity, donot foresee compulsory internal sense connections with specific psalms; 5) it is a group of poems that, without any external references to the Psalter, is deeply linked to it through hiddenquotation, paraphrase, etc. ${ }^{10}$.

B.-I. Antonych's psalms are undoubtedly new creatures, although there are hints at the original source. However, it should be noted that the definition of "psalm" is not strictly genre, but rather indicates the sourcefirst-basis of new creation. The Psalter itself, whose sacred content is defined as an inspired conversation of the human heart with God, is an inter-genre association from a literary point of view. By genre content, the psalms are divided into hymns, cries, prayers, wisdoms, prophecies, invective, etc."11.

The poem "Te Deum laudamus", which is ideologically linked to both the Psalter and the Liturgy, has a significant place in "The Great Harmony".

The earth is a golden-stringed harp of Your glory,

day and night - a prayer of longing and hope,

the sky is the ultimate human goal,

all together - the grand harmony glorifies $\mathrm{You}^{12}$.

This poem is analogous to the hymn "Holy, holy, holy, is the Lord of armies: all the earth is full of his glory", taken from the vision of the prophet Isaiah, who saw heaven and God, to whom angels sang praise songs (Isa. 6, 1-5). In the quoted poemit is also traced the features of the 150 th Psalm: "Give praise to God in his holy place: give him praise in the heaven of his power. Give him praise for his acts of power: give him praise in the measure of his great strength. Give him praise with the sound of the horn: give him praise with corded instruments of music. [...] Let everything which has breath give praise to the Lord. Let the Lord be praised!" (Ps. 150, 1-5). Besides that, "Te Deum laudamus" has common features with the song of

10 Бетко I. Біблійні сюжети і мотиви в українській поезії XIX - початку XX століття. ZielonaGyra - Kijyw, 1999. Ст. 115-116.

11 Бетко I. Біблійні сюжети і мотиви в українській поезії XIX - початку XX століття. ZielonaGyra - Kijyw, 1999. Ст. 117.

12 Антонич Б. І. Повне зібрання творів / Передмова Миколи Ільницького; Упорядкування і коментарі Данила Ільницького. Львів: Літопис, 2009. Ст. 92. 
St. Ambrose, Bp. Mediolanskiy "We praise You, God": "We praise You, God, we recognize You, Lord. All the earth glorifiesYou, Eternal Father. All the angels to You, the heavens and all the powers to You, cherubim and seraphim sing to You with incessant voices: Holy, holy, holy Lord God of armies! $!^{13}$. Both the psalms and the song of St. Ambrose was, without doubt, known to B.-I. Antonych and became an organic part of his poetry.

Blessings is an integral and important part of worship: "Glory to You, our God, Glory to You" or "Glory to You, Lord, Glory to You", "Glory to God in the highest, and peace on earth, and pleasantness in people"."Through blessings, glorification of Love, Wisdom, Mercy of the Lord during worship, - emphasizes D. Bolharskiy, -a person joins the Divine life, thereby healing his soul damaged by sin and passions, stands on a grace way of salvation and, if he lives without breaking the commandments of God, in the spirit of Christian love, then has the opportunity to imitate eternal life"14.

A stylistic figure such as anaphora promotes the imagery and rhythm of the biblical text, and the closer unification of its components. In the Psalms of King David, it is quite common, in the religious poetry of B.-I. Antonych it also has an active use. The poem "Te Deum laudamus, II" will serve as an illustration of the artistic use of this figure:

For You the sea plays a radiant, spirited psalm,

for You the wind sings echoing, thunderous songs,

for You the fierce storm disturbs the bottom of the sea,

for You the grass stirs in a silken whisper ${ }^{15}$.

Sometimes the poet skillfully combines anaphora with epiphora:

When you call in the night - He is there,

when you call for help - He is there,

when you search - He is there,

you already have Him for He is within ${ }^{16}$.

${ }^{13}$ Прийдіте поклонімся: Молитовник. 5-те вид.випр. Львів: Свічадо, 2007. Ст. 887.

14 Болгарський Д. До проблеми розуміння православного богослужебного співу. Наукові записки: Збірник наукових статей Національного педагогічного університету ім. М. Драгоманова. Вип. 40. Київ, 2001. Ст. 74.

15 Антонич Б. І. Повне зібрання творів / Передмова Миколи Ільницького; Упорядкування і коментарі Данила Ільницького. Львів: Літопис, 2009. Ст. 112.

16 Антонич Б. І. Повне зібрання творів / Передмова Миколи Ільницького; Упорядкування і коментарі Данила Ільницького. Львів: Літопис, 2009. Ст. 93. 
The frequent use of the anaphora by the poet emphasizes the sacred dimension of the poem: the repetition of the word witnesses about its importance, and so directs, raises the thoughts and feelings of the person upwards, to the transcendent ${ }^{17}$.

Is there anything special and artistic in the request prayers by which the lyrical hero of the collection appeals to the Lord? The answer to this can be found in the poem "Kyrie elejson" ("Lord Have Mercy!").

In the poem of the same name by B.-I. Antonych the appeal "Lord Have Mercy!" sounds refrain. "The writers also use the repetition of prayer as a principle of sacred worldview in any religion. Sometimes the fragmentary reproduction of prayer promotes "prayerfulness" as a worldview" $" 18$.

I lift up my hands in mute ecstasy,

Darkened eyes shine with it.

Give sweet utterance to my lips for You.

Lord have mercy

from the silence of night. [...]

I tear the unknown, opaque distance with my eyes,

my soul again is already peaceful and healthy,

Give creative, free, ripe language to my lips!

Lord have mercy

from the helplessness of the word ${ }^{19}$.

$\mathrm{H}$. Tokman remarks that the work is caught by one emotional state that can be called religious ecstasy. The development of ecstatic feelings in the work concerns the response of a person to the experience of the Holy, the hero changes himself during his stay in ecstasy. The poet asks God for the gift of the word, opposing it to the silence of the night, the brand of separation, the darkness of sight, the feebleness of the word... The artist wants to escape from the captivity of alienation from the essential Being,

${ }^{17}$ Papla E. Muzyczna Liturgia Bohdana Ihora Antonycza (na podstawie cyklu "Wielka Harmonia") Ukraina. Między językiem a kultura. Studia Ruthenica Crakoviensia: 1. I Pod. red. B. Zienkiewicz-Tomanek, A. Falowskiego. Kraków: Universitas, 2003. St. 375.

${ }^{18}$ Бовсунівська Т. Молитва як літературний жанр. Дивослово. 2003. № 7. Ст. 3.

19 Антонич Б. І. Повне зібрання творів / Передмова Миколи Ільницького; Упорядкування і коментарі Данила Ільницького. Львів: Літопис, 2009. Ст. 112-113. 
to overcome this alienation by his poetic word, he prays to God - and feels how God helps him: the soul "becomes calm and healthy", he "tears"with hiseyes, and eventually "breaks off" the dark opaque distance. The poet's desire for the inspired word, that is dear to God, to the sharp, lightlywinged, creative, free, mature language, was probably heard, because the hero becomes stronger in spirit, becomes more courageous" ${ }^{\prime 20}$. We interpret this Antonych's poem after H. Tokman as a figurative expression of what P. Tillich called "an ecstatic experience of spiritual power".

In the liturgical practice, the prayer "Lord Have Mercy!" is often used because it "contains all the anguish of a person for God" ${ }^{21}$ and the person's will is entirely subordinated to God's will. By its roots the prayer"Lord Have Mercy!"goes back to the Old Testament, but its complete consummation gets in the Gospel: the lepers, aspiring clearing, called Jesus Christ, "Jesus, Teacher, have mercy on us," a blind man who wished to see and felt the presence of Christ, said, "Jesus, Son of David, have mercy on me". Later these lines formed the basis of the widespread in the Eastern Christian tradition of Jesus' prayer, "the greatness of which is discovered even by its construction, which consists of two parts: the first one, that is," Lord Jesus Christ, the Son of God, "leads the mind into the story of life of Jesus Christ, or, as the Holy Fathers speaks about, "contains the whole Gospel", and the second part, that is, "have mercy on me sinful", depicts the story of our powerlessness and sinfulness ${ }^{22}$.

Metropolitan Antony Surozkiy notices in his thoughts on prayer that the word "have mercy" is the Greek word "eleison", which comes from the same root as "eleon", which means "oil". In the Old and New Testaments, we meet this notion in a series of parables and events that allow us to fully understand the meaning of this word. This is also the book of Genesis, when, after the flood, the dove returns to Noah with an olive branch, which symbolizes about the cessation of God's anger. In the parable of the merciful Samaritan, oil is used to relieve pain and heal wounds.

20 Токмань Г. Збірка Б.-І. Антонича “Велика гармонія” у діалозі з екзистенціальним богослов’ям. Слово $i$ час. 2002. № 12. Ст. 51.

21 Соловій М., о. Божественна Літургія: Історія - розвиток - пояснення. Львів: Свічадо, 1999. Ст. 215.

${ }^{22}$ Щирі розповіді Прочанина своєму духовному отцеві / Пер. 3 рос. Д. Кічі. Львів: Свічадо, 2005. Ст. $124-125$. 
So, "mercy" and "have mercy" are words of the same root that express tenderness, that's why when we ask God to have mercy on us, it is not only to get rid of His anger, we ask for love $\mathrm{e}^{23}$. The similar reflections isfound in "The Honest Stories of the Pilgrim to His Spiritual Father": "It is impossible out of this word ("have mercy on me") to express the desire and request of a poor, sinful and submissive soulwiser, clearer and more essential. No other expression would be as exhaustive and complete as this one. For example, if you said, "Forgive me!", "Forgive sins!", "Forgive iniquity!", "Make up for my crimes!"- then all that would only express one request about theliberation from punishment.But the expression"have mercy on me" means not only caused by fear desire to ask for forgiveness, but it also contains a true cry of son's love, hoping for the mercy of God and submissively admitting his powerlessness. A cry for pardon, not only for the forgiveness of sins, but also for the outpouring of mercy, manifested in the gift of spiritual power from God, a spirit that strengthens us in the fight against temptation and helps to conquer the sinful inclination",24.

Usually, after a heart is broken by repentant prayer, joy and a desire to glorify God come. This regularity is observed in "The Great Harmony" by B.-I. Antonych, where the request-repentant tone of the poem "Kyrie elejson" naturally goes into praising - "Magnificat". The poet's heart aspires to sing to God "a commendable psalm", "a mighty song", "a pure song", as the psalmist once called: "The Lord of armies is with us; the God of Jacob is our high tower" (Ps. 46, 7), "Sing Him a new song" (Ps. 33, 3), "I will make a new song to you, o God" (Ps. 144, 9).

\section{Sacred musical symbols in the creative work of Bohdan-Igor Antonych}

Music has always made a significant influence on person's spiritual life. "The experience of prayerful worship embodied in songs is anevidence of the spirit of the highest Mind, in which there are the rhythm,

${ }^{23}$ Сурожский А., митр. Школа молитвы. Клин: Христианская жизнь. С. 79-80.

${ }^{24}$ Щирі розповіді Прочанина своєму духовному отцеві / Пер. $з$ рос. Д. Кічі. Львів: Свічадо, 2005. Ст. 125. 
breath, and life of the Kingdom of Heaven" ${ }^{25}$. E. Ronki generally believes that "only the music of poetry and the poetry of music can establish a connection with God and reality [...] In Scripture, it is not enough to reflect on God or speak about Him - you also need to sing. Singing is more than a simple recitative. Singing is more than a voice and a sound, because it enlists music, artistic experience of beauty, culture and history of the people [...] In prayer, the song enlists the body, the world and history. The poetry of music is added to the music of poetry [...] Christ presents himself, the Word is presented through beauty in music and poetry" 26 .

In ancient times, people expressed their aspiration for the Divine through word and music. There are several vivid examples in the Old Testament books to confirm this view. For example, when the evil spirit tormented Saul, David played on harps for the king and the spirit retreated. Also, when the prophet Elisha wanted to ask something from God, he ordered to bring the harper. "But now, get me a player of music, and it will come about that while the man is playing, the hand of the Lord will come on me and I will give you the word of the Lord: and they got a player of music, and while the man was playing, the hand of the Lord was on him" (2 Kings 3, 15). During the reign of David, over 4,000 musicians played and sang in the temple allday and night (1 Chron. 9, 33; 23, 5). But the fullest meaning of spiritual singing is represented in the psalms which convey the state of the soul when it is filled with the Lord, however only a person filled with the Spirit of God can sing for the Creator from the fullness of his heart: "and will make a song of praise to your name" (Ps. 18, 50), "I will make a song, truly I will make a song of praise to the Lord" (Ps. 27, 6), "For God is the King of all the earth; make songs of praise with knowledge" (Ps. 47, 7), "I will make songs to the Lord all my life; I will make melody to my God while I have my being" (Ps. 104, 33), and others. In the New Testament, St. Ap. Paul also calls upon Christians to say among themselves "psalms and hymns and spiritual songs"

25 Болгарський Д. До проблеми розуміння православного богослужебного співу. Наукові записки: Збірник наукових статей Національного педагогічного університету ім. М. Драгоманова. Вип. 40. Київ, 2001. Ст. 74.

${ }^{26}$ Ронкі Е. Закоханий і здивований Бог / Пер. з італ. К. Зінченко. Львів: Свічадо, 2015. Ст. 33-38. 
(Eph. 5,19). Metropolitan Andrew Sheptytskiy, remembering the expression of the Holy Fathers"He who sings, he prays doubly", rightly called singing "a wonderful symbol of prayer": "Sung prayer corresponds to human nature and the natural debts of a person against the Most High [...] in singing, the person, during her life who destroys and torments byincessant disorder and disharmony, internal struggle and external blows, finds what is the ideal of life, that is, the order and harmony" ${ }^{27}$. These words of Metropolitan Andrew are the suitable key to the reading of collection "The Great Harmony" by B.-I. Antonych.

The name itself "The Great Harmony" is an original key to the interpretation of the collection, because the concept "harmony" coordination, "harmonious" - is dominant in it, is repeated in 12 poems, organizes a figurative system that allows you to consider it as a metaimage $^{28}$. The thought that the world has a musical nature was extremely close to Antonych. The Christian God is the highest harmony, the tuning fork to which poets "tune" other spheres of the musical universe. God, person and nature are united in the only one chord, in the only one musical rhythm $^{29}$ :

In a heart wrapped in the scarves of quiet peace,

melodious, harmonious is every tone.

The distance echoes with just barely audible harps,

wind tunes the night with the tuning fork of God. [...]

Let us listen to the great concert in the evening as

God places his hands on the piano of the world ${ }^{30}$.

In the limit of his spiritual growth, the poet realizes that "it is necessary a little for happiness: harmony" ("Amen"), "harmony in your heart - you do not need anything more" ("Naivety"); in the poem "Litania"

27 Шептицький А., митр. Про церковний спів (Декрет Собору, читаний дня 25 квітня 1941 р. ст. ст.). Письма-послання Митрополита Андрея Шептицького, ЧСВВ, з часів німецької окупаиії. Йорктон, Саск. (Канада), 1969. Ч. 2. Ст. 56-57.

28 Якубчак Н. Поетика ліричного циклу Б.-І. Антонича. Наукові записки. Том 48. Філологічні науки. Київ: Видавничий дім “Києво-Могилянська академія”, 2005. Ст. 28.

${ }^{29}$ Papla E. Muzyczna Liturgia Bohdana Ihora Antonycza (na podstawie cyklu "Wielka Harmonia") Ukraina. Między językiem a kultura. Studia Ruthenica Crakoviensia: 1. I Pod. red. B. Zienkiewicz-Tomanek, A. Falowskiego. Kraków: Universitas, 2003. St. 377.

30 Антонич Б. І. Повне зібрання творів / Передмова Миколи Ільницького; Упорядкування і коментарі Данила Ільницького. Львів: Літопис, 2009. Ст. 86. 
"harmony of the soul" is identified with the caress of faith. B.-I. Antonych comes to the important recognition that the highest harmony is God:

He gives melody to every thing.

He is harmony, He is a musical chord,

He is the tuning fork tuning your heart,

He is Perfect, Majestic Sound ${ }^{31}$.

In the quotations above, God is not only the source of the harmony of the human heart, but also the cosmic harmony, because"He gives melody to every thing" and that's why the collection is called not simply "harmony" but "The Great Harmony". In the lines of the poem "Deus Magnificus" the poet skillfully weaves several musical terms that are closely connected to each other in music, and in the poetic context they become expressive and imaginative instruments for signifying the Lord. The poet was not confined to the embodiment of the general interpretation of "harmony", but penetrated into the deeper, special meanings and associated them with the various states of the human soul in the process of spiritual struggle, adjusting relationships with the Creator. B.-I. Antonych also calls God a musical chord, because the Creator brought everything from non-existence to existence, gave order where chaos reigned, called every creature to life in perfection, "in wisdom you have made them all" (Ps. 103, 24). However, with the creation of the world, the role of God is not completed, because He not only gives life, but also supports it, thinks through everything in the smallest details. That's why it is entirely justified in this context that B.-I. Antonych calls God "the tuning fork tuning your heart". Why the heart? Because in the Bible the heart marks, basically, the spiritual essence of the human personality. The very heart makes the spiritual decision inattitude to God: it chooses to believe in Him or disobedience to Him. So B.-I. Antonych, according to Christian tradition, perceives the world and life in it as a perfect act of creation, in which there is no place for chaos and disharmony. They appear only when a person voluntarily and consciously breaks off his connection with the Creator,

31 Антонич Б. І. Повне зібрання творів / Передмова Миколи Ільницького; Упорядкування і коментарі Данила Ільницького. Львів: Літопис, 2009. Ст. 93. 
or when he is in a state of intensified spiritual struggle. Thus, in the poem "Veni Creator" the poet is aware of himself in enharmonic contrast to the cosmic harmony of the universe:

You are the chord of cosmic harmony all around,

I am enharmonic - forced to struggle among the waves:

and when my weak soul should fall downward,

muffle the dissonance and smite a helpless soul with thunder ${ }^{32}$.

The loss of mercy, anxiety, incoordination in the soul of the lyric hero, the intense processes of spiritual struggle are associated in B.-I. Anthonych with dissonance and enharmony. Such states can be overcome only with the belief that the Lord, as a perfect harmony, will fill up with Himself the human "enharmony" by the power of the Holy Spirit, as if by a fiery sword, He would cut through the tempter's shackles, absorb the dissonance of the soul, and fill it with the light sound. The Mother of God, to whom the poet appeals in the poem "Ave Maria", is also empowered to "to calm the enharmony":

Fly to me, Immaculate Virgin, quietly stand above a poor heart,

With your hand halt the enharmony of this trembling. [...]

Soar and bring a healing cure in a hard struggle,

calm the enharmonic gnashing of the harp of the heart ${ }^{33}$.

Besides the concepts "harmony", "chord", "enharmony", "dissonance", "melody", there are also other musical terms in "The Great Harmony": "strings", "concert", "tuning fork", "harp", "lute", "lyre", "violin","piano","bells".

The "harp", which has a rich sacred symbolism - an attribute of King David and the angels' choirs, deserves a special attention, however it is known that the psalms were accompanied by playing the harp. The author chose the epithets "gold-stringed", "million-stringed" to the harp. "May I become your harp," the lyric hero appeals to the Lord. Thus, both in the Christian tradition and in the works of Antonych, the harp has at first "praiseworthy" purpose. However, Antonych's harp sounds not only for

32 Антонич Б. І. Повне зібрання творів / Передмова Миколи Ільницького; Упорядкування і коментарі Данила Ільницького. Львів: Літопис, 2009. Ст. 101.

33 Антонич Б. І. Повне зібрання творів / Передмова Миколи Ільницького; Упорядкування і коментарі Данила Ільницького. Львів: Літопис, 2009. Ст. 101. 
the glorification of God the Father, but in "Mater Gloriosa" it accompanies a prayer-glorifying in honor of the Mother of God:

Play, harps, play, lyres, play lutes, play zitherns,

pour out joy, wash away cares, shroud grief with the mantle of spring.

Let the silver-waved, tiny-grained river beds abundantly splash,

fragrant roses and lustrous pearls of the Lord in golden rain from the heavens ${ }^{34}$.

The image-symbol of the harps also has a deep symbolic content, which we will try to discover with E. Ronki. In Psalm 49 we read: "Give attention to this, all you peoples; let your ears be open, all you who are living in the world [...] From my mouth will come words of wisdom; and in the thoughts of my heart will be knowledge. I will put my teaching into a story; I will make my dark sayings clear with music" (Ps. 49, 2-5). That's why, in order to the psalmist declare something important, he does not have enough heart feeling, it is not enough to simply explain this mysterious parable of life - he appeals for help to the music and poetry. For his revelation, he uses harps - as if they were a tool for understanding God and being. The psalmist's harps catches somewhat mysterious, but this is not due to rational concepts - a beauty, that gives birth to astonishment, emotion, capture and feeling, acts here [...] Fighting the closeness of the mystery and fighting the closeness of God for the sake of His appearance, iscarried out in various ways: Jacob fights physically near the ford of Yabbok, Elijah fights with the knife and the fire of the word, Moses with stone tablets, the psalmist with scream and harps, poetry and music. A sacrament explained by the harps ceases to be a mystery, becoming a sensuousexperience, a preface to the theological aesthetics. Thus, God is changed from amystery and a problem into an experience, becoming in the center of being as a song in which the body and spirit are united $^{35}$. So, B.-I. Antonych writes:

I want to play for Him,

to strum the dulcimer with my hand.

34 Антонич Б. І. Повне зібрання творів / Передмова Миколи Ільницького; Упорядкування і коментарі Данила Ільницького. Львів: Літопис, 2009. Ст. 110.

35 Ронкі Е. Закоханий і здивований Бог / Пер. з італ. К. Зінченко. Львів: Свічадо, 2015. Ст. 32-35. 
A hundred strings, like silver grating,

with which the cedar is strung ${ }^{36}$.

In the poem "The Resurrection", the bell is the image-symbol that invokes the prayer and accompanies it. This is the resurrection and welcoming bell, it impels the whole universe to worship the Resurrected Christ:

Bells peal silkily, brilliantly, baroquely,

bells peal, the entire earth rushes to give greeting,

bells peal silkily, they awaken the Sun's Word,

bells peal, for my soul is rising ${ }^{37}$.

The bell is "a musical sermon, it informs of belief, of a life lit up by its light, awakens a sleepy conscience" ${ }^{, 3}$. However, the bell symbol is only an original "bridge" to the mega-symbol of this work - the "Sunny Word", that is, the Resurrected Christ. The lyrical hero has throughout personal, not just a ritualistic perception of the greatest Christian holiday, because "my soul is resurrected", just like in the poem"Glory in the Highest""Today the Lord was born in the stream of my heart" 39 .

In B.-I. Antonych there is also present the ancient Christian motive, where a person is an instrument in the hands of God:

Sing, my soul, an immaculate song to the Lord,

O be joyful, o rejoice!

Point Your path to ecstatic eyes,

let me become Your harp ${ }^{40}$.

The lyrical hero entreats to become a harp in the hands of God, that is, he asks the Lord's hand to touch the gentle strings of his soul, because only by doing God's will a person can fully reveal himself to the world, in the Antonych's comprehending - to "sound". Researcher Iryna Betko remarks

36 Антонич Б. І. Повне зібрання творів / Передмова Миколи Ільницького; Упорядкування і коментарі Данила Ільницького. Львів: Літопис, 2009. Ст. 97.

37 Антонич Б. І. Повне зібрання творів / Передмова Миколи Ільницького; Упорядкування і коментарі Данила Ільницького. Львів: Літопис, 2009. Ст. 95.

38 Мень А. В. Таинство, Слово и Образ. Православное богослужение. Москва, 2001. Ст. 14.

39 Антонич Б. І. Повне зібрання творів / Передмова Миколи Ільницького; Упорядкування і коментарі Данила Ільницького. Львів: Літопис, 2009. Ст. 88.

40 Антонич Б. І. Повне зібрання творів / Передмова Миколи Ільницького; Упорядкування і коментарі Данила Ільницького. Львів: Літопис, 2009. Ст. 113. 
that the image-symbol of the prophets' harp is a capacious embodiment of poetic creative work $^{41}$. Through the act of creation the Universe B.I. Antonych tries to understand the purpose of the artist, who, likening himself toGod,also becomes the creator of a new reality.

\section{CONCLUSIONS}

The collection of religious poetry "The Great Harmony" by BohdanIgor Antonych is distinguishes itself by the originality of artistic rethinking of biblical and liturgical texts. Most of the poems of B.-I. Antonych, which are the part of "The Great Harmony", is the stylization of separate prayers ("Ut in omnibus glorificetur Deus" ("That in all things God may be Glorified"), "Veni Sancte Spiritus!", “Come, Holy Spirit!", “Amen”, "Te Deum laudamus I, II" ("We Praise Thee, O Lord I, II"),"Praise be to God" "Salve Regina!” (“Hail, Holy Queen!”), “Kyrie elejson!” ("Lord Have Mercy!"). They are related in genre to the psalms, which in B.-I. Antonych are undoubtedly new creatures. They are different in tonality, but this is mostly prayers of God's glorification, in which the lyrical hero is admired by the omnipotence of God the Father, his majestic presence in the Universe, the humility of the Son of God and the wealth of the gifts of the Holy Spirit. In the collection an important place is given to prayer, in which the author asks God for heavenly and earthly goods, but most of all, for harmony in the heart, and around this concept the author forms a whole constellation of musical terms.

The keyword "harmony" is associated with "chord", "enharmony", various forms of "song" and "singing". "Strings", "concert", "tuning fork", as well as the names of musical instruments: "harp", "lute", "lyre", "violin", "piano" and "bells", also belongsto this semantic field. The harp, which is an important sacred symbol, since the psalms were accompanied by playing the harp, deserves special attention. The author chose the epithets of polyphonic sound - "gold-stringed", "million-stringed" to the harp."May I become your harp," the lyric hero appeals to the Lordin the poem"Magnificat".

41 Бетко I. Біблійні сюжети і мотиви в українській поезії XIX - початку XX століття. ZielonaGyra - Kijyw, 1999. С. 69. 
In general, it can be affirmed that "The Great Harmony" is one great prayer "as a process of personal, intimate, secret communication of the believer with God; as a sincere and frank expression of your feelings to the highest being in the world; as a purification of thought from everything secondary and outside; as a reverent dissolutionof your "I" in the object of worship" 42 .

\section{SUMMARY}

Much of the works that have been included in collection "The Great Harmony" by Bohdan-Igor Antonych are poetic replaying of the Divine Liturgy.For example, works "Kyrie Eleison", "Gloria in Excelsis", "Credo", "Sanctus", "Agnus Dei" have identical names with parts of Liturgy of the Latin rite, and poems "Veni Sancte Spiritus", "Deus Magificus", "Te Deum Laudamus", "Veni Creator", "Confiteror", "Mater Dolorosa", "Mater Gloriosa" and "Salve Regina" are ideologically related to the hymnographic Christian tradition.

The collection "The Great Harmony" is named asoriginal prayer of the poet, in which the motives of glorifying God and request, but request not for small earth's things, but for the gift of faith, for the gifts of the Holy Spirit, for the harmony of the soul, are dominated. If we talk about the liturgical aspect of Antonych's poetry, it should be noted that a noticeable feature of the poems mentioned above is their rooting in the psalms and other liturgical texts. In "The Great Harmony" the poet is often uses anaphora, epiphora, refrain and so on. At the genre level, the author uses psalms, hymns, songs, in his works there are biblical stylizations, allusions from the Scripture and famous liturgical works.

Both in the Eastern and in the Western rites, the Divine Liturgy is accompanied by singing, that's why music and singing are important means for achieving the mystical state of unity between a man and God in the works of B.-I. Antonych. Besides the musical terms "harmony", "chord", "enharmony", "dissonance", "melody", the poetry of B.-I. Antonychis also abounded with such images as"strings", "concert",

${ }^{42}$ Антофійчук В. “Молитва, як сонце, вічна...” (Жанр молитви в українській літературі). “Святі чуття, закладені в молитву...”: Антологія украӥнської молитви. У 2-х кн. Чернівці: Рута, 1996. Кн. 1. Ст. 4. 
"tuning fork", "harp", "lute", "lyre", "violin", "piano", "bells", which are often symbolized and are carried an important semantic loading.

\section{REFERENCES}

1. Антонич Б. I. Повне зібрання творів / Передмова Миколи Ільницького; Упорядкування і коментарі Данила Ільницького. Львів: Літопис, 2009. 968 с.

2. Антофійчук В. “Молитва, як сонце, вічна...” (Жанр молитви в українській літературі). “Святі чуття, закладені в молитву...”: Антологія украӥнської молитви. У 2-х кн. Чернівці: Рута, 1996.Кн. 1. Ст. 3-10.

3. Бетко I. Біблійні сюжети і мотиви в українській поезії XIX початку XX століття. ZielonaGyra - Kijyw, 1999. 160 с.

4. Бетко I. Осмислення нумінозного досвіду в поезії БогданаІгоря Антонича. Бетко I. Українська релігійно-філософська поезія. Emanu розвитку. Katowice: Wydawnictwo Uniwersytetu Śląskiego, 2003. Ст. 174-209.

5. Бовсунівська Т. Молитва як літературний жанр. Дивослово. 2003. № 7. Ст. 3-8.

6. Болгарський Д. До проблеми розуміння православного богослужебного співу. Наукові записки: Збірник наукових статей Національного педагогічного університету ім. М. Драгоманова. Вип. 40. Київ, 2001. С. 74-77.

7. Калинець I. Знане i незнане про Антонича: Матеріяли до біографії Богдана Ігоря Антонича. 2-ге вид., випр. і доп. Львів: Друкарські куншти, 2011. 276 с.

8. Лєпахін В. Ікона та іконічність. Львів: Свічадо, 2001. 288 с.

9. Мень А. В. Таинство, Слово и Образ. Православное богослужение. Москва, 2001. 285 с.

10. Олійник О. Надгробок на могилі щастя. Весни розспіваноӥ князь. Слово про Антонича: Статті, есе, спогади, листи, поезії. Львів: Каменяр, 1989. Ст. 362-369.

11. Прийдіте поклонімся: Молитовник. 5-те вид.випр. Львів: Свічадо, 2007. 988 с. 
12. Ронкі Е. Закоханий і здивований Бог / Пер. з італ. К. Зінченко. Львів: Свічадо, 2015. 80 с.

13. Соловій М., о. Божественна Літургія: Історія - розвиток пояснення. Львів: Свічадо, 1999. 440 с.

14. Сурожский А., митр. Школа молитвы. Клин: Христианская жизнь. 496 с.

15. Токмань Г. Збірка Б.-І. Антонича “Велика гармонія” у діалозі з екзистенціальним богослов’ям. Слово і час. 2002. № 12. Ст. 41-53.

16. Шептицький А., митр. Про церковнийспів (Декрет Собору, читаний дня 25 квітня 1941 р. ст. ст.). Письма-послання Митрополита Андрея Шептицького, ЧСВВ, з часів німеџької окупащії. Йорктон, Саск. (Канада), 1969. Ч. 2. Ст. 56-63.

17. Шмеман А. Символы и символизм византийской литургии: Литургические символы и их богословское истолкование. Синопсис. 2001. № 4/5. Ст. 74-80.

18. Щирі розповіді Прочанина своєму духовному отцеві / Пер. 3 рос. Д. Кічі. Львів: Свічадо, 2005. 232 с.

19. Якубчак Н. Поетика ліричного циклу Б.-І. Антонича. Наукові записки. Том 48. Філологічні науки. Київ: Видавничий дім “КиєвоМогилянська академія”, 2005. Ст. 24-31.

20. Papla E. Muzyczna Liturgia Bohdana Ihora Antonycza (na podstawie cyklu "Wielka Harmonia") Ukraina. Między językiem a kultura. Studia Ruthenica Crakoviensia: 1. / Pod. red. B. ZienkiewiczTomanek, A. Falowskiego. Kraków: Universitas, 2003. S. 371-378.

\section{Information about the author: Dmytriv I. I., Candidate of Philology,} Associate Professor at the Department of Ukrainian Literature and Theory of Literature,

Drohobych State Pedagogical University named after Ivan Franko 24, Taras Shevchenko str., Drohobych, Lviv region, 82100, Ukraine 